\title{
PERCUTANEOUS TREATMENT OF ANEURYSMAL BONE CYST WITH CALCITONIN AND METHYLPREDNISOLONE
}

\section{TRATAMENTO PERCUTÂNEO DE CISTO ÓSSEO ANEURISMÁTICO COM CALCITONINA E METILPREDNISOLONA}

\author{
Marcelo Bragança dos Reis Oliveira ${ }^{1,2,3}$, Walter Meohas ${ }^{1}$, Ronan Ribeiro Silva ${ }^{3}$, Gustavo Sobral de Carvalho ${ }^{2,3}$, \\ Fernanda Carvalho de Queiroz Mello ${ }^{2}$, Marcos Eduardo Machado Paschoal ${ }^{2}$ \\ 1. Instituto Nacional de Traumatologia e Ortopedia, Rio de Janeiro, Brazil. \\ 2. Universidade Federal do Rio de Janeiro, Rio de Janeiro, Brazil. \\ 3. Escola de Saúde do Exército, Rio de Janeiro, Brazil.
}

\section{ABSTRACT}

Objective: To introduce the intralesional calcitonin and methylprednisolone percutaneous injection method, which results in the promotion of primary aneurysmal bone cyst (ABC) healing. Methods: A retrospective cohort study involving 76 patients diagnosed with $A B C$ was performed between 2005 and 2014. Patients treated with calcitonin and methylprednisolone injection and who underwent more than 2 years of follow-up were considered eligible for the study $(n=47)$. The Enneking staging and Capanna classification systems were used during the initial evaluation. Treatment response was assessed by Rastogi radiographic grading based on the degree of healing. $X^{2}$ and Wilcoxon signed-rank tests and odds ratio calculations were used in the statistical analysis with a 5\% significance level. Results: The proximal tibia extremity was the most commonly affected site (17.0\%). Thirty-three (70.3\%) ABC cases were staged as B3 and 28 (59.7\%) were classified as type II. The average number of injections performed was 2.8 per patient, with an average reduction of the initial lytic area of $83.7 \%(p$-value $=0.00001)$. Satisfactory results for $91.4 \%(n=43$; $p$-value $=0.00001)$ were obtained and 5 recurrences occurred. No side effects were observed. Conclusion: Intralesional calcitonin and methylprednisolone percutaneous injection is a minimally invasive, effective, and safe method for promoting primary ABC healing. Level of evidence IV, Type of study: case series.

Keywords: Bone cyst. Calcitonin. Methylprednisolone.

\section{RESUMO}

Objetivo: Apresentar o método de injeção intralesional percutânea de calcitonina e metilprednisolona para promover a ossificação do cisto ósseo aneurismático (COA). Métodos: Foi realizado um estudo retrospectivo de coorte envolvendo 76 pacientes com diagnóstico de COA entre 2005 e 2014. Os pacientes tratados com injeção de calcitonina e metilprednisolona e acompanhados durante mais de dois anos foram considerados elegíveis para o estudo $(n=47)$. Foram utilizados o sistema de estadiamento de Enneking e a classificação de Capanna durante a avaliação inicial. A resposta ao tratamento foi avaliada pela classificação radiográfica Rastogi, com base no grau de cicatrização. Os testes $X^{2}$, Wilcoxon e o cálculo da razão de chances foram utilizados na análise estatística com nivel de significância de 5\%. Resultados: A extremidade proximal da tíbia foi o local mais frequente (17,0\%). Trinta e três $(70,3 \%)$ COA eram B3 e 28 (59,7\%) do tipo II. O número médio de injeções aplicadas foi de 2,8 por paciente, com redução média da área lítica inicial de 83,7\% ( $p=0,00001)$. Resultados satisfatórios para 91,4\% ( $n=43 ; p=0,00001)$ dos pacientes e houve cinco recidivas. Nenhum efeito colateral foi observado. Conclusão: A injeção intralesional percutânea de calcitonina e metilprednisolona é um método minimamente invasivo, eficaz e seguro para promover a ossificação do COA. Nível de evidência IV, Tipo de estudo: série de casos.

Descritores: Cistos ósseos. Calcitonina. Metilprednisolona.

Citation: Oliveira MBR, Meohas W, Silva RR, Carvalho GS, Mello FCQ, Paschoal MEM. Percutaneous treatment of aneurysmal bone cyst with calcitonin and methylprednisolone. Acta Ortop Bras. [online]. 2018;26(5):314-9. Available from URL: http://www.scielo.br/aob.

\section{INTRODUCTION}

Aneurysmal bone cyst (ABC) was first described by Jaffe and Liechestein in 1942 91). The World Health Organization defines $\mathrm{ABC}$ as an "expanding osteolytic lesion consisting of blood-filled spaces of variable size separated by connective tissue containing trabeculae of bone or osteoid tissue and osteoclast giant cells." It is considered an active or aggressive benign bone tumor that may result in high morbidity and recurrence if not properly treated. ${ }^{1}$
ABC accounts for approximately $1 \%$ of all primary bone tumors and most commonly occurs during the first and second decades of life, with a slight predominance in females. ${ }^{1,2}$ The main affected sites are the distal end of the femur and proximal end of the tibia., ${ }^{1,2}$ The optimal treatment for $\mathrm{ABC}$ is controversial and several methods have been reported. ${ }^{1-3}$ The recurrence rate ranges from $5 \%$ to $40 \%$, depending on the method of treatment used..$^{1-3}$ Currently, the most widely used method is curettage combined with grafting. ${ }^{1-4}$ This

All authors declare no potential conflict of interest related to this article.

Work conducted at the Instituto Nacional de Traumatologia e Ortopedia Jamil Haddad, Rio de Janeiro, RJ, Brazil.

Correspondence: Serviço de Traumato-Ortopedia do Hospital Universitário Clementino Fraga Filho da Universidade Federal do Rio de Janeiro. Rua Rodolpho Paulo Rocco, 255, Cidade Universitária, Ilha do Fundão, Rio de Janeiro, RJ, Brazil. 21941-913. marceloreis@hucff.ufrj.br 
method results in a high relapse rate, prolonged recovery period, risk of bleeding, and damage to surrounding structures essential for maintaining the function of the affected segment, especially in vertebral and pelvic lesions. ${ }^{4-6}$ Therefore, less invasive methods to promote $\mathrm{ABC}$ healing with reduced surgical morbidity, especially in areas with difficult access, are increasingly being used. Accordingly, percutaneous intralesional injection of sclerosing agents and healing stimulators has proven to be a promising alternative to conventional surgical treatment. ${ }^{1,3,6-9}$

Recently, given the presence of osteoclastic giant cells in this bone tumor, the receptor activator of nuclear kappa-B ligand has been used as a potential target for promoting $A B C$ healing through its inhibition by denosumab. ${ }^{10}$ However, in case studies, calcitonin and methylprednisolone percutaneous intralesional injection also promoted the healing of ABCs located in the spine, where the risks and surgical morbidity are higher. ${ }^{7-9}$ Given these favorable results, we have been using this method to treat primary ABCs in long bones as a minimally invasive and low-cost alternative in our institution since 2003. Therefore, the present study describes a calcitonin and methylprednisolone intralesional injection method that promotes primary $\mathrm{ABC}$ healing.

\section{MATERIAL AND METHODS}

\section{Study population}

A retrospective cohort study involving 76 patients with $A B C s$ diagnosed between January 2005 and December 2014 at a single institution was performed.

After the initial selection of patients from the database of the Pathological Anatomy Unit, the following exclusion criteria were applied: secondary $\mathrm{ABC}, \mathrm{ABC}$ located in the spine, initial surgical treatment, and incomplete radiographic evaluation.

Twenty-nine patients were excluded according to the following criteria: secondary ABC ( $n=10)$, spine $A B C(n=3)$, surgery as the initial treatment $(n=10)$, and absence of complete radiographic evaluation available $(n=6)$. The study group consisted of 47 patients with primary $\mathrm{ABC}$ treated with calcitonin and methylprednisolone intralesional injection.

\section{Diagnosis}

The method used for diagnosis of primary $A B C$ in all patients involved histopathological study of specimens collected by percutaneous biopsy of the lesion using a bone marrow biopsy needle guided by computed tomography or radioscopy. The anatomopathological, clinical, and radiological correlations were performed by a pathologist who specialized in bone pathology to confirm the diagnosis.

\section{Variables}

To determine the demographic profile of the sample, age at diagnosis and gender were collected by reviewing the medical records. The following radiographic variables were assessed at diagnosis: lesion volume, staging according to the Enneking system, ${ }^{11}$ affected bone, and location of the tumor according to the Capanna classification $^{12}$ (Table 1).

\begin{tabular}{c|c} 
Table 1. Capanna classification. \\
\hline Type & Morphological characteristics \\
\hline I & Central \\
\hline II & Central affecting the entire bone diameter \\
\hline III & Eccentric \\
\hline IV & Subperiosteal \\
\hline V & Subperiosteal extending to soft parts \\
\hline
\end{tabular}

\section{Method}

The procedure followed the same protocol for all patients and was conducted by two surgeons who used sedation and local anesthesia with an aseptic technique, percutaneously guided radioscopy in appendicular lesions, and computed tomography in pelvic lesions. The method consists of introducing an 11-gauge bone marrow biopsy needle into the lesion with the guidance of imaging until it reaches the largest lytic portion of the tumor. The cyst walls are manually scarified using the end of the needle to break the non-healed septa and the hematic content is aspirated. Then, a 5-ml syringe containing a solution of $200 \mathrm{IU}$ calcitonin and $120 \mathrm{mg}$ methylprednisolone and another syringe containing $10 \mathrm{ml}$ distilled water are attached to the bone marrow biopsy needle through a 3-way connector. Subsequently, the solution is injected into the lesion (Figure 1). Then, the biopsy needle introduced into the lesion and still containing the residual solution is rinsed with distilled water, which is injected from the second syringe, so that the entire dose of drugs reaches the lesion. Finally, pressure dressing is performed and maintained for 3 days. The patient is discharged on the same day as the procedure and the healing status is followed-up monthly through radiographs or computed tomography scans according to the location of the lesion. According to the classification proposed by Rastogi, ${ }^{6}$ the procedure is repeated if no satisfactory healing of the lesion occurs after 2 months.

\section{Treatment response}

Treatment results were measured based on monthly evolutionary radiographic evaluation until the lesion healed and quarterly evaluation during the first 2 years after healing. Evaluation consisted of comparing the percentage of volumetric reduction of lytic bone involvement before and after treatment and quantifying healing at each follow-up appointment according to the classification proposed by Rastogi6 (Table 2). At the end of the follow-up period, the outcome was classified as satisfactory (excellent or good) or unsatisfactory (poor or unresponsive)

The criteria for treatment discontinuation were satisfactory result assessment or treatment failure, which was defined as healing less than $50 \%$ after the first two injections or disease progression before reaching degree II of healing as identified by an increase in lytic area. Recurrence was defined as an increase of the lytic area after reaching degree I or II (excellent or good) of healing. Surgical treatment was performed if percutaneous treatment failure occurred. However, in the recurrence, the percutaneous procedure was still indicated. The minimum follow-up period after healing was 2 years.

\section{Statistical analysis}

The ratios of cases that did and did not responded to treatment were compared using the $\chi 2$ test. The Wilcoxon signed-rank test was used to compare the lytic areas before and after treatment. Analysis of the effect of study variables on treatment response was performed by calculating the odds ratio with a 95\% confidence interval. SPSS $10.0^{\circledR}$ software was used and $p$-value $<0.05$ was considered significant.

\section{Research ethics}

This research project numbered as 50105815.7.0000.5273, which was approved by our institution's Research Ethics Committee, is in accordance with the Helsinki Declaration for experiments involving humans. All participants read and signed the informed consent form.

\section{RESULTS}

The sample of 47 patients consisted of 23 men and 24 women. The average age was 17.5 years (4-54 years). Patient characteristics are outlined in Table 3.

$\mathrm{ABC}$ was predominantly located in the proximal tibia extremity $(19.1 \% ; n=9)$. Figure 2 shows the distribution of $A B C$. 


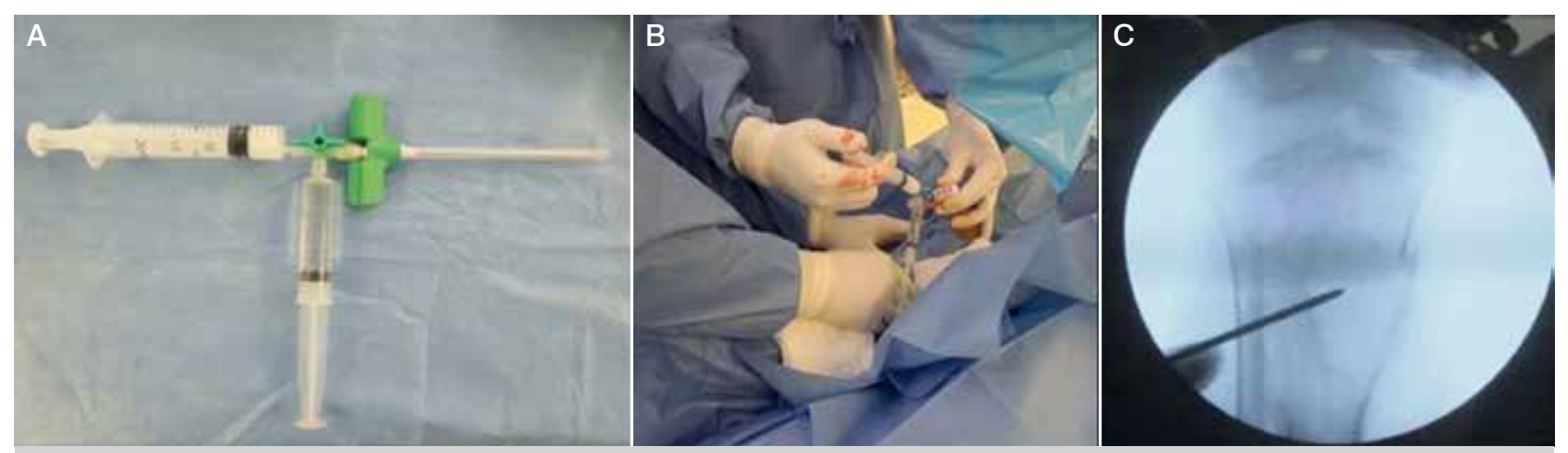

Figure 1. Injection method. A) Biopsy needle with a 3-way connector attached to two syringes containing the calcitonin and methylprednisolone solution and distilled water. B) Intralesional injection of calcitonin and methylprednisolone. C) Radioscopic control of the injection.

Table 2. Radiographic classification according to Rastogi.

\begin{tabular}{c|c|c}
\hline Degree & Characteristic & Result \\
\hline I & Residual lesion $<25 \%$ & Excellent \\
\hline II & Residual lesion $25-50 \%$ & Good \\
\hline III & Residual lesion $50-75 \%$ & Poor \\
\hline IV & Residual lesion $>75 \%$ & Unresponsive \\
\hline
\end{tabular}

Table 3. Patient characteristics

\begin{tabular}{c|c|c}
\hline Variable & $\mathbf{n}$ & $\%$ \\
\hline Average age (range) & 17.5 years (4-54) & \\
\hline$\leq 16$ years & 28 & 59.5 \\
\hline$>16$ years & 19 & 40.5 \\
\hline Gender & & \\
\hline Male & 23 & 48.9 \\
\hline Female & 24 & 51.1 \\
\hline Average volume (range) & $50.6 \mathrm{~cm}^{3}(9.4-163.6)$ & \\
\hline Enneking & & \\
\hline B1 & - & - \\
\hline B2 & 14 & 29.7 \\
\hline B3 & 33 & 70.3 \\
\hline Capanna & & \\
\hline I & 5 & 10.6 \\
\hline II & 28 & 59.7 \\
\hline III & 13 & 27.6 \\
\hline IV & 1 & 2.1 \\
\hline V & - & - \\
\hline
\end{tabular}

Figure 3 shows the number of procedures required to promote $A B C$ healing according the number of treated patients. A total of 131 procedures were performed (average $=2.8$ /patient), with an $83.7 \%$ average reduction of the initial lytic area $(p$-value $=0.00001)$. Only 1 procedure was performed in 9 patients (19.1\%), 2 procedures were performed in 14 (29.7\%), 3 procedures were performed in 10 (21.2\%), 4 procedures were performed in 7 (14.8\%), 5 procedures were performed in 5 (10.6\%), 6 procedures were performed in 1 (2.1\%), and 7 procedures were performed in 1 (2.1\%; Figure 4). The average length of treatment was 10.3 months (2-59.5 months) and the average length of follow-up was 45.5 months.

According to the radiographic classification used to assess the treatment response, $91.4 \%(n=43)$ of patients showed satisfactory (excellent or good) results ( $p$-value $=0.00001)$ and $72.3 \%(n=34)$ showed complete cyst healing (degree I; Table 4).
Figure 4 shows an outcome classified as excellent (degree I) at the end of treatment.

Table 5 shows the average number of procedures performed according to the study variables and indicates the initial average volume of lesions and the residual percentage at the end of treatment. Among the variables studied as possible prognostic factors, younger patients ( $\leq 16$ years) had a higher percentage of good results than did older patients ( $>16$ years) $(92.8 \%$ and $89.4 \%$, respectively), but the difference was non-significant. B2 ABCs (active) had better outcomes (100\%; $n=14$ ) than B3 ABCs (aggressive) $(87.8 \% ; n=29)$, but the difference was non-significant. Conversely, patients with Capanna type II lesions had worse outcomes (89.2\%; $n=25)$ than all others (94.7\%; $n=18)$, although the difference was also non-significant (Table 6).

During follow-up, 5 patients (10.6\%) experienced recurrence. Therefore, the percutaneous procedure was repeated; 3 patients progressed with an excellent or good response after 1 or 2 injections. The other 2 patients were surgically treated due to disease progression. One progressed with a pathological fracture, although the lesions subsequently healed.

\section{DISCUSSION}

$A B C$ is a rare, locally aggressive, benign tumor with a prevalence of 1.4 cases per 100,000 individuals. ${ }^{1,2}$ The lesion may occur in any bone and at any age, although more than $50 \%$ occur in long bones and approximately $80 \%$ of the cases involve patients younger than age 20 years. ${ }^{1,2}$ Approximately $70 \%$ of $A B C$ s are primary and the remaining $30 \%$ are secondary to hemorrhagic degenerative events in preexisting bone lesions, including giant cell tumor, simple bone cyst, and chondroblastomas. ${ }^{1}$

The vascular theory of pathogenesis postulates that $A B C$ is a reaction to a local hemodynamic disorder resulting in increased venous pressure and formation of a dilated vascular bed in the affected bone. ${ }^{1}$ However, the vascular theory has been surpassed by the clonal theory based on more recent studies describing the recurring presence of a specific chromosome translocation, $t(16 ; 17)$ (q22;p13), in primary ABC and insulin-like growth factor 1 (IGF-1) expression. ${ }^{13}$ These findings confirm that primary $A B C$ is a true tumor and not a pseudotumoral lesion, as previously believed, which may explain the effect of drugs with angiostatic, cytostatic, and bone-forming properties in promoting healing. ${ }^{14}$

Several methods have been described for ABC treatment, and the best therapeutic option is still undergoing debate. Recurrence within 24 months after treatment is common and ranges from 10 to $59 \%$ depending on the method used. ${ }^{2,6}$ Intralesional curettage combined with grafting is still the most often indicated method. ${ }^{1,15}$ 


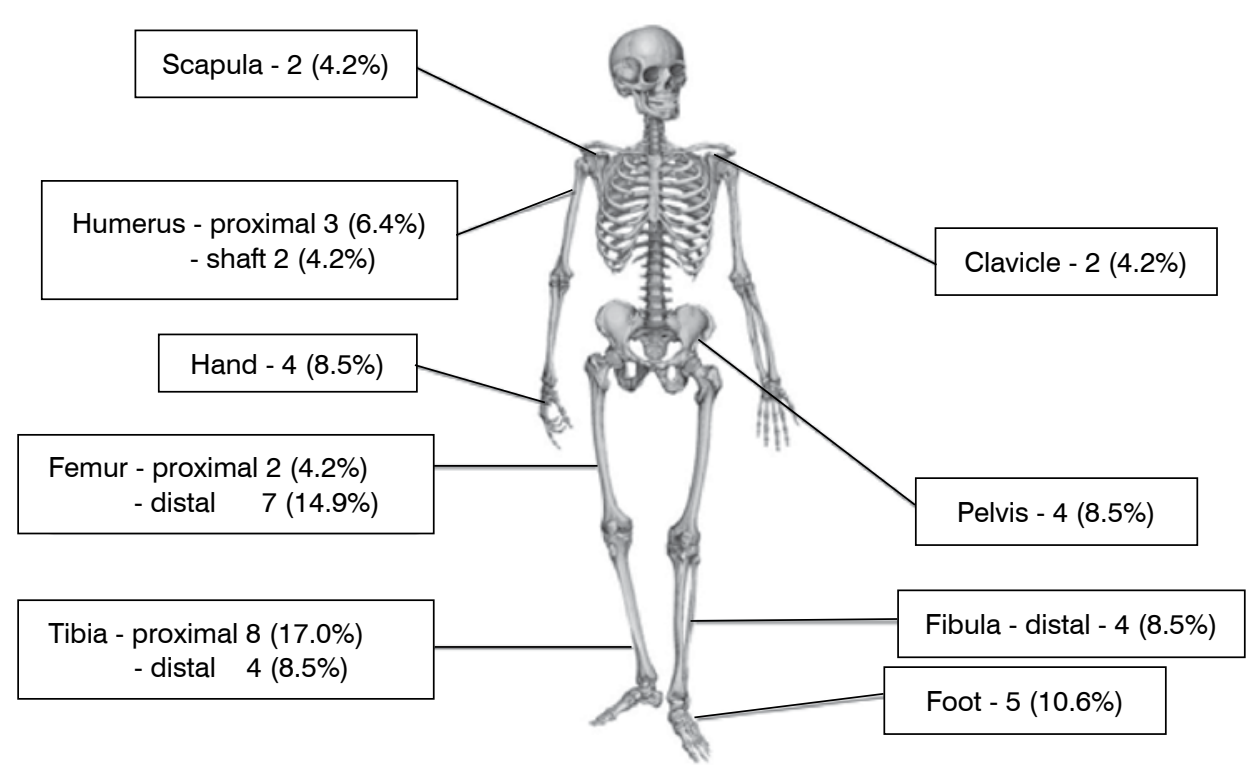

Figure 2. Location of aneurysmal bone cysts.

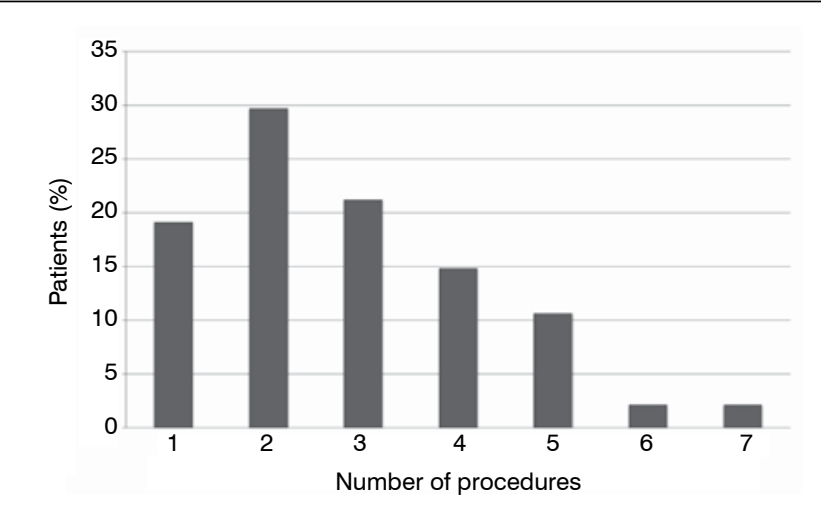

Figure 3. Distribution of the number of procedures at the end of the follow-up period.

However, surgical treatment may result in extensive bone defects and involves a significant risk of bleeding and damage to key anatomical structures. In addition to profuse bleeding, the risk of lesions of the physeal plate among growing children also renders surgical treatment challenging. ${ }^{7}$ Therefore, non-surgical methods, including sclerotherapy, selective arterial embolization, and injection of healing-inducing agents, are gaining relevance in the management of these patients. ${ }^{6,7,15,16}$ High success rates were reached using those different treatment modalities. However, no prospective, randomized, controlled studies comparing them with conventional surgical treatment have been published in the literature. Thus, the choice of method is usually guided by the experience and preference of the surgeon.

Percutaneous methods have been increasingly used for $A B C$ treatment to cause the least possible morbidity to patients. Selective arterial embolization and sclerotherapy are the most widely used non-surgical methods. ${ }^{15}$ However, calcitonin and methylprednisolone percutaneous intralesional injection is a promising alternative that is expected to deliver lower complication rates. ${ }^{7,9,17}$

The first study describing the use of calcitonin for $A B C$ treatment was published by Szendroi, who retrospectively assessed 7 patients
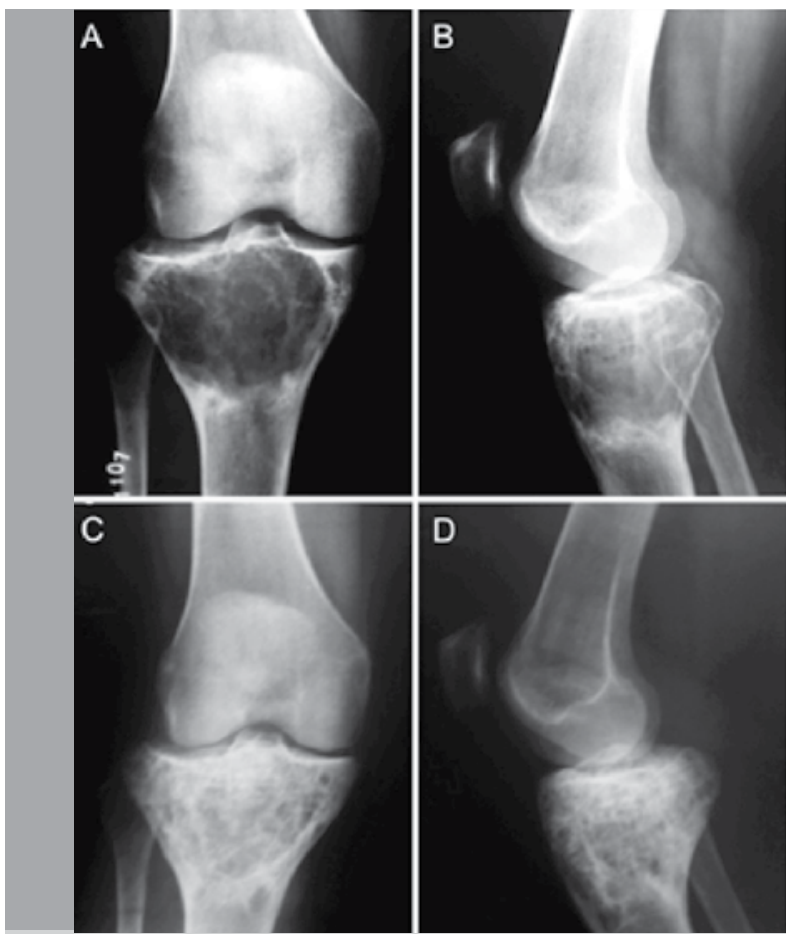

Figure 4. Excellent outcome. A/B) Plain films showing a large $A B C$ in the proximal tibia before treatment. $C / D)$ Plain films 4 months after the end of treatment showing complete $\mathrm{ABC}$ healing.

\begin{tabular}{c|c|c}
\multicolumn{3}{|c}{ Table 4. Treatment outcome at the end of the follow-up period } \\
\hline Degree of healing & & \\
\hline & N & $\%$ \\
\hline I & 34 & 72.3 \\
\hline II & 9 & 19.1 \\
\hline III & 3 & 6.3 \\
\hline IV & 1 & 2.1 \\
\hline
\end{tabular}


Table 5. Average number of procedures.

\begin{tabular}{c|c|c|c}
\hline \multicolumn{2}{c|}{ Variable } & \multicolumn{2}{c}{} \\
\hline Gender & Procedures & Volume $\left(\mathbf{c m}^{3}\right)$ & $\%$ Residual \\
\hline Male & 3.0 & & \\
\hline Female & 2.6 & 58.8 & 16.3 \\
\hline Age & & 43.2 & 16.3 \\
\hline$\leq 16$ years & 3.1 & & \\
\hline$>16$ years & 2.4 & 45.2 & 19.1 \\
\hline Enneking & & 55.1 & 20.3 \\
\hline B2 & 2.2 & & \\
\hline B3 & 2.9 & 52.0 & 13.9 \\
\hline Capanna & & 56.6 & 18.4 \\
\hline II & 2.9 & 46.1 & 16.4 \\
\hline I, III, IV, or V & 2.5 & 54.7 & 18.7 \\
\hline \multicolumn{2}{|l}{}
\end{tabular}

Table 6. Univariate analysis.

\begin{tabular}{c|c|c|c|c|c}
\hline Category & \multicolumn{2}{|c|}{ Good result } & & & \\
\hline Age & $\mathbf{N}$ & $\%$ & OR & $95 \% \mathrm{Cl}$ & p-value \\
\hline$\leq 16$ years & 28 & 92.8 & 1.52 & $0.19-11.9$ & 0.68 \\
\hline$>16$ years & 19 & 89.4 & & & \\
\hline Gender & & & & & \\
\hline Male & 24 & 91.3 & 0.95 & $0.12-7.40$ & 0.96 \\
\hline Female & 23 & 91.6 & & & \\
\hline Enneking & & & & & \\
\hline B2 & 14 & 100 & 4.42 & $0.22-87.8$ & 0.32 \\
\hline B3 & 33 & 87.8 & & & \\
\hline Capanna & & & & & \\
\hline II & 28 & 89.2 & 0.46 & $0.04-4.82$ & 0.51 \\
\hline I, III, IV, or V & 19 & 94.7 & & & \\
\hline & & & & &
\end{tabular}

receiving 3 weekly injections for 5 weeks. In this series, 3 cysts completely healed, 3 cysts partly healed, and the treatment of 1 patient was discontinued due to hypersensitivity reaction. ${ }^{18}$

The combination with methylprednisolone as an adjuvant was first described for the treatment of cervical spine ABC in children at increased risk for devastating complications due to inadvertent embolization of the vertebral artery because invasive procedures may result in vertebral instability. $7,9,19$ Gladden and collaborators proposed that the combination of methylprednisolone with calcitonin would result in a synergistic effect to promote $A B C$ healing because of the angiostatic and fibroblast formation-inhibitory activities of the corticoid combined with the inhibitory effect on osteoclasts and trabecular bone formation-stimulating effects of calcitonin. ${ }^{7-9}$ The authors reported the case of a child with $A B C$ who underwent 2 injections with 6-month intervals. Lesion healing occurred after
2 years and 7 months without side effects. ${ }^{7}$ Rai and Collins ${ }^{19}$ and Ohashi and collaborators ${ }^{9}$ also published similar results using this method; they observed progressive healing and no adverse effects. Only two injections were performed over several months in both studies. ${ }^{9,19}$

To our knowledge, no studies assessing the method used with a larger case series than that of the present study have been published in the literature. Articles initially published were limited to case reports of ABCs located in the axial skeleton.-9,19 The articles identified in the literature review include 7 patients with primary $A B C$ treated with the calcitonin and methylprednisolone intralesional injection method. The protocols used in these studies vary regarding the dose and dosing interval, but the results show good treatment response. ${ }^{7-9,17,19}$

The high percentage of satisfactory results $(91.4 \% ; n=43)$ and a low recurrence rate $(10.6 \%, n=5)$ were observed in this cohort. The lesions showed an $83.7 \%$ average reduction of the initial lytic area; 2.8 procedures were required per patient, with no reported side effects (vomiting and/or convulsions). The fixed dose of calcitonin (200 IU) and methylprednisolone (120 mg) used in this study was established empirically without variation according to the size of the lesion, similar to previous studies. However, further studies are needed to determine the relationship between the initial lesion volume and the response to the dose used. The number of procedures required to promote healing varied in this study, thus suggesting the existence of treatment response determinants. However, the study was not able to determine the treatment response-related factors. Therefore, further studies are necessary to establish whether factors previously described as determinants of worse prognosis also affect the response to this treatment method, including vascular pattern, histological characteristics, and age of patients. ${ }^{20}$

The main advantages of this study are the relevant case series, the inclusion of appendicular lesions, and consistent satisfactory outcomes of the largest known case series of patients with primary $\mathrm{ABC}$ treated with the same protocol (calcitonin and methylprednisolone injection) at a single institution. The treatment was proven effective and safe, with a low relapse rate during follow-up. Healing progressed after further treatments and surgical treatment was not precluded in necessary cases. Potential advantages of the described method include the following: lower local morbidity, especially in lesions with difficult surgical access; increased patient acceptance; shorter hospital stays; and low frequency of side effects or hypersensitivity reactions. However, treatment should only be started after proper radiological evaluation and histopathological confirmation of diagnosis. We believe that two to three injections at 2 to 3 month intervals adequately treat most $\mathrm{ABCs}$

\section{CONCLUSION}

Calcitonin and methylprednisolone intralesional injection is a safe and effective method with a low relapse rate that promotes $A B C$ healing. The method has been consolidated as a minimally invasive treatment alternative to reduce surgical morbidity associated with $\mathrm{ABC}$, although prospective studies comparing this method with surgical treatment should be performed to definitively establish calcitonin and methylprednisolone intralesional injection as a firstline treatment.

AUTHORS' CONTRIBUTIONS: Each individual author contributed individually and significantly to the development of this work. MBRO (0000-0003-19867002): wrote, reviewed, performed the procedures, analyzed the data, evaluated the plain films; WM (0000-0003-1402-9667): performed the procedures and wrote the article; RRS (0000-0002-7200-6634): analyzed the data; and reviewed the article; GSC (0000-0002-0645-4308) participated at the surgeries, collected the data, evaluated the plain films and reviewed the article; FCCQM (0000-0003-3250-6738): drafted and reviewed the article and contributed to the intellectual concept of the study; MEMP (0000-0002-8699-3933): wrote the article, performed statistical analysis and contributed to the intellectual concept of the study and the entire research project. *ORCID (Open Researcher and Contributor ID). 


\section{REFERENCES}

1. Rapp TB, Ward JP, Alaia MJ. Aneurysmal bone cyst. J Am Acad Orthop Surg. 2012;20(4):233-41.

2. Wang EH, Marfori ML, Serrano MV, Rubio DA. Is curettage and high-speed burring sufficient treatment for aneurysmal bone cyst? Clin Orthop Relat Res. 2014;472(11):3483-8.

3. Batisse F, Schmitt A, Vendeuvre T, Herbreteau D, Bonnard C. Aneurysmal bone cyst: a 19-case series managed by percutaneous sclerotherapy. Orthop Traumatol Surg Res. 2016;102(2):213-6.

4. Papagelopoulos PJ, Choudhury SN, Frassica FJ, Bond JR, Unni KK, Sim FH. Treatment of aneurismal bone cysts of the pelvis and sacrum. J Bone Joint Surg Am. 2001;83-A(11):1674-81.

5. Reddy KIA, Sinnaeve F, Gaston CL, Grimer RJ, Carter SR. Aneurismal bone cysts: do simple treatments work? Clin Orthop Relat Res. 2014;472(6):1901-10.

6. Rastogi S, Varshney MK, Trikha V, Khan SA, Choudhury B, Safaya R. Treatment of Aneurismal bone cysts with Percutaneus Sclerotherapy using Polidocanol. A review of 72 cases with long-term follow-up. J Bone J Surg Br. 2006;88(9):1212-6.

7. Gladden ML, Gillingham BL, Hennrikus W, Vaughan LM. Aneurismal bone cys of the first Cervical Vertebrae in a Child treated with percutaneous intralesional injection of calcitonin and methylprednisolone. A case report. Spine (Phila Pa 1976). 2000;25(4):527-30.

8. Tonomura ET, Ramos P, Hemais PM, Marchiori E, Gasparetto EL. Aneurysmal bone cyst at C2: Imaging evaluation after intralesional injection of calcitonin and methylprednisolone. Arq Neuro-psiquiatr. 2008;66(3-B):711-5.

9. Ohashi M, Ito T, Hirano T, Endo N. Percutaneus intralesional injection of Calcitonin and Methylprednisolone for treatment of na Aneurismal bone cyst at C-2. J Neurosurg Pediatr. 2008;2(5):365-9.

10. Lange T, Stehling C, Frohlich B, Klingenhofer M, Kunkel P, Schneppenheim $\mathrm{R}$, et al. Denosumab: a potential new and innovative treatment option for aneurysmal bone cysts. Eur Spine J. 2013;22(6):1417-22.

11. Enneking WF. A system of staging musculoskeletal neoplasms. Clin Orthop Relat Res. 1986;(204):9-24.

12. Capanna R, Bettelli G, Biagini R, Ruggieri P, Bertoni F, Campanacci M. Aneurysmal cysts of long bones. Ital J Orthop Traumatol. 1985;11(4):409-17.

13. Ye Y, Pringle LM, Lau AW, Riguelme DN, Wang H, Jiang T, et al. TRE17/USP6 oncogene translocated in aneurysmal bone cyst induces matrix metalloproteinase production via activation of NF-kappaB. Oncogene. 2010;29(25):3619-29.

14. Pelle DW, Ringler JW, Peacock JD, Kampfschulte K, Scholten DJ $2^{\text {nd }}$, Davis $\mathrm{MM}$, et al. Targeting receptor-activator of nuclear kappaB ligand in aneurysmal bone cysts: verification of target and therapeutic response. Transl Res. 2014;164(2):139-48.

15. Varshney MK, Rastogi S, Khan SA, Trikha V. Is sclerotherapy better than intralesional excision for treating aneurysmal bone cysts? Clin Orthop Relat Res. 2010;468(6):1649-59.

16. Shiels WE 2nd, Beebe AC, Mayerson JL. Percutaneous doxycycline treatment of juxtaphyseal aneurysmal bone cysts. J Pediatr Orthop. 2016;36(2): 205-12.

17. Meohas W, Lopes ACS, Moller JVS, Barbosa LD, Oliveira MB. Parosteal aneurysmal bone cyst. Rev Bras Ortop. 2015;50(5):601-6.

18. Szendroi M, Antal P, Liszka G, Kónya A. Calcitonin therapy of aneurismal bone cysts. J Cancer Res Clin Oncol. 1992;119(1):61-5.

19. Rai AT, Collins JJ. Percutaneous treatment of pediatric aneurismal bone cyst at $\mathrm{C} 1$ : A minimally invasive alternative: A case report. AJNR Am J Neuroradiol. 2005;26(1):30-3.

20. Steffner RJ, Liao C, Stacy G, Atanda A, Attar S, Avedian R, et al. Factors associated with recurrence of primary aneurysmal bone cysts: is argon beam coagulation an effective adjuvant treatment? J Bone Joint Surg Am. 2011;93(21):1221-9. 